\title{
Review of Intellectual property and theories of justice, co- edited by Axel Gosseries, Alain Marciano, and Alain Strowel. London: Palgrave Macmillan, 2008, 296 pp.
}

\author{
MADHAVI SUNDER \\ University of California, Davis
}

More than a quarter-century ago property scholars interrupted the hegemony of a law and economics discourse focused exclusively on efficiency with broader theories about property and social relations. As the New Jersey Supreme Court declared in 1971 in the historic case of State $v$. Shack, "[p]roperty rights serve human values". Modern property law balances plural values beyond efficiency to consider personhood, health, dignity, liberty, and distributive justice.

In contrast, at the start of the 21 st century intellectual-property scholarship remains moored to a singular economic account. In the modern day, intellectual property (IP) is understood almost exclusively as being about incentives. Its theory is utilitarian, but with the maximand simply creative output. Law's goal is to calibrate the optimal length of copyright and patent terms to promote efficient innovation. Critiques of the recent expansion of intellectual-property law's breadth, scope and duration resonate in the same language. Progressive law and economics scholars argue that too much IP can impede innovation, locking up the building blocks necessary for further innovation.

It should be noted that understandings of intellectual-property law were not always this way. Copyright law emerged out of the Enlightenment in England in the early 18th century; limited rights to authors broke the perpetual monopoly in intellectual works held by printers, encouraging the creation of new works and their broad dissemination to a democratically engaged public. Patent law has always sought to encourage access to knowledge, requiring owners to share knowledge of their inventions in exchange for limited monopoly rights, rather than protecting the knowledge as a trade secret. And trademark law originated in theories of unfair competition and tort, not property law. But over the last few decades law and economics scholars have reimagined intellectual-property law, portraying it as solely an instrumental mechanism to incentivize creativity (copyright), invention 
(patents), and industry (trademarks). Because information is assumed by its nature to be nonrivalrous and nonexcludable, the concern is that free-riding will eliminate any incentive to produce information. The insertion of property rights, the theory goes, incentivizes the production of information, which will then inure to society's benefit through the market mechanism, with those willing and able to pay being permitted to consume the information. Others might free ride, but only where high transaction costs would make marketplace exchanges unlikely. In short, market failure is cited as the raison d'être for intellectual property, explaining copyright, patent, and even trademark.

But intellectual property today is more than simply a tool for incentivizing creative production in the form of more things, from iPods to R2D2. Intellectual-property laws bear considerably upon central features of human flourishing, from the developing world's access to food, textbooks, and essential medicines, to the ability of citizens everywhere to democratically participate in political and cultural discourse, to the capacity to earn a livelihood from one's intellectual contributions in making our world. And yet, to date much scholarship in this area insists that law's focus is efficiency alone. The dominance of this singular, narrow economic discourse has rarely been challenged.

This is now beginning to change. Emergent social movements, around access to HIV drugs and other essential medicines, have combined forces with open source advocates in the software and Internet fields to insist upon "access to knowledge" as a human right. Highlighting the constitutive role of knowledge in promoting central human capabilities, from health to education to the right to participate in and enjoy culture, these social movements are beginning to influence theoretical understandings of intellectual-property law, as well. The result has been increased interdisciplinary engagement with intellectualproperty law, from fields as diverse as anthropology and science and technology studies to philosophy. Each of these disciplines brings an important lens to contemporary intellectual-property law, and challenges the dominance of the singular economic vision. Anthropology helps us to consider more deeply a central purpose of this law: the promotion of culture. Anthropology suggests that law's current focus on the production of more things misunderstands the essence of culture itself-participatory community and shared meaning. Science and technology studies reveal that technology is not merely science, but also a social and political artifact. 
Philosophers attend to the moral questions raised by intellectual property. Such questions are legion today with the exponential growth of intellectual property to cover everything from medicines to seeds, and with the steady march of this law into every corner of the globe, including the poorest countries on Earth. Even in the least developed countries, the dominant approach has remained law and economics, relying upon the market to spur creation. But this leads to the mistake that drugs for baldness are more important than drugs for malaria because the former enjoys a multi-billion dollar market, while those who need the latter are too poor to offer much to save their own lives. Understanding intellectual property as the incentive-to-create reduces to the claim that the ability to pay, as evidenced in the marketplace, should determine the production and dissemination of knowledge and culture.

Intellectual property and theories of justice (Gosseries, et al. 2008) is a much-needed intervention into current debates over intellectual property and social justice, a topic once thought irrelevant to IP. ${ }^{1}$ The book considers the theoretical foundations of intellectual-property claims-are these rights rooted in Lockean claims, or are they merely tools to promote innovation? Utilitarians, who seek to maximize the overall social welfare, show little concern for the distribution of social welfare, but the contributors to this volume ask whether IP law ought to attend to maldistribution of resources and wealth that flow from IP law, from pricing medicines out of the reach of the poor to the redistribution of wealth from the IP-consuming South to the IP-producing North. Perhaps most importantly, the book is focused on plural values, for example, not just efficiency or equality, but also freedom.

As Axel Gosseries writes in the introduction, "Not having enough money to buy non-generic drugs clearly raises problems of both equality and freedom. Therefore, redistributing resources, even at the cost of taxing people, amounts to redistributing real freedom" (p. 9). Gosseries argues that while efficiency concerns are important, they "are not the end of the matter. They need to be plugged into theories of justice" (p. 16). Scholars in this volume consider not only the relevance of Locke and Nozick for understanding intellectual-property rights (some argue they are less relevant than many think), but also of Rawls and G. A. Cohen.

The strength of the volume is not so much in introducing new visions of intellectual property (for example, as a human right, or as a

\footnotetext{
${ }^{1}$ See generally, Chander and Sunder 2007.
} 
tool for promoting central human capabilities). Rather, the essays here question and probe deeply the oversimplified justification of modern intellectual-property law as incentives-to-create. Theorists in this volume recognize they can take efficiency seriously "in ways that go beyond merely defending a trade-off or convergence", in Gosseries words (p. 16). Giovanni Battista Ramello, for example, uses economic analysis to show that exclusive rights in knowledge decrease the overall productivity of knowledge by undermining its social purpose. Ramello argues that the concerns of efficiency and social justice advocates converge because both want knowledge to be put to its most productive use: to serve societies (p. 86).

It is helpful to push beyond the traditional incentives theory from both within and without economics. Economic theories of knowledge as a unique good, of development and human capabilities, and of distributive justice can helpfully broaden existing law and economics approaches to IP. But interdisciplinary accounts of intellectual property that go beyond economics are also necessary. Indeed, we must insist on plural accounts of this law, which regulates culture, freedom, democratic participation, and equality itself. Most of the contributions to this volume do not go this far, largely taking the tack that theories of justice may be added on to the dominant approach.

Still, there is much to be learned and gained from the critiques of IP's incentive theory herein, and many are quite powerful. Seana Shiffrin provocatively asks: even if incentives are necessary, are they just? She distinguishes between various demands for incentives, finding some more fair than others. Claims that incentives are necessary to recoup costs or maintain a livelihood are fair-she says-but they would justify only weak IP rights and nothing like the maximalist rights that exist today (p. 96). In contrast, the demands for stronger and more farreaching rights we hear today offer a different incentive argument: that creative people will refuse to make or share their works in the absence of a monopoly reward. In the case where "talented people ransom their talents, withholding their creative products in order to demand greater compensation", Shiffrin concludes that such arguments are inconsistent with the tenets of a Rawlsian vision of a just society, in which "a just citizen accepts that social and natural talents as well as one's market position are arbitrary from a moral point of view" (p. 101). Even if one does not endorse a Rawlsian vision of justice, the question of inconsistent or unfair motives remains. For example, says Shiffrin, we 
ought to be skeptical of those who seek to use copyright to protect their works against critique and comment, because these norms are inconsistent with our society's commitment to free speech. Shiffrin further asks whether a legal system that acquiesces to immoral demands is not itself unjust (p. 102).

At the end of the 20th century too few legal decision-makers asked such questions and intellectual-property rights were expanded with abandon, propelled by the simple elegance of a dominant law and economic understanding of intellectual property as incentives-to-create. Now, at last, the dominance of that account is being challenged by scholars in a variety of disciplines questioning the assumptions, effects, and goals of this law, which reach far beyond incentives. The analyses here are sophisticated and compelling, teaching much about the ways in which philosophy can illuminate and enrich economic analysis of law.

\section{REFERENCES}

Chander, Anupam, and Madhavi Sunder. 2007. Is Nozick kicking Rawls' ass?: IP and social justice. U. C. Davis Law Review, 40 (3): 563-580.

Madhavi Sunder is a professor of law at the University of California, Davis. Her book, iP: YouTube, MySpace, our culture, arguing for the incorporation of social and cultural theory into intellectual-property law, is forthcoming from Yale University Press.

Contact e-mail: <msunder@ucdavis.edu> 